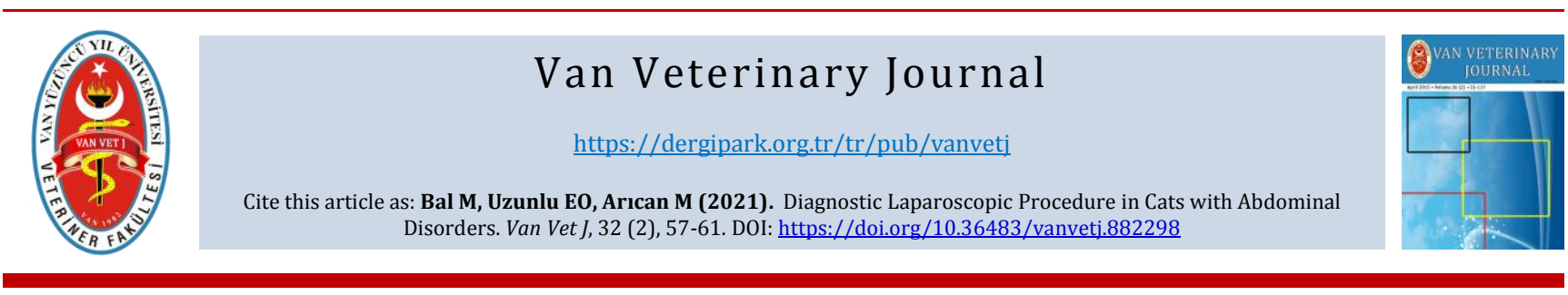

\title{
Diagnostic Laparoscopic Procedure in Cats with Abdominal Disorders
}

\author{
Maide BAL* (1) Elgin Orçum UZUNLU (1) Mustafa ARICAN \\ Selcuk University, Faculty of Veterinary Medicine Department of Surgery, 42130, Konya, Turkey \\ Received: 17.02.2021 \\ Accepted: 07.07.2021
}

ABSTRACT The use of diagnostic and therapeutic laparoscopy has increased tremendously in human medicine in the last 10 years. The widespread acceptance of laparoscopy is due to technological advances in equipment and the impressive results of this noninvasive modality compared to invasive surgery. Many procedures performed in humans are accepted for veterinary medicine due to the convenience, efficiency, and low morbidity of many procedures. Techniques have been developed in veterinary medicine for noninvasive evaluation of various organs including the liver, extrahepatic biliary system, pancreas, kidneys, spleen, intestine, and genitourinary system. Biopsy procedures of these organs can be performed in most patients with minimal risk. Twenty cats of different breeds, ages, genders, and weights with abdominal complications and a history of trauma were used as study material. After the clinical examination of the patients, laparoscopic surgery was performed. Clinical examination revealed that the cases were stable. Liver, gall bladder, stomach, kidney, intestines, urinary bladder, ovary, and spleen were clearly observed during the laparoscopic examination. While almost all of the cases are not encountered with any pathology in the organs; It was observed comfortably that in one case the spleen color changed regardless of age. Laparoscopy enabled controlled cytosynthesis in some cases. This article reviews that the equipment and techniques should be required for performing laparoscopy in cats. As a result, it was concluded that laparoscopic examination yielded more successful results in the examination of abdominal organs or the application of surgical techniques on the biopsy of pathological masses compared to other diagnostic methods. Further studies with a larger group of cats should be considered to compare the efficacy of laparoscopic procedures.

Keywords: Abdomen, Cat, Laparoscopy.

\section{ÖZ \\ Kedilerde Diagnostik Laparoskopik Uygulama Sonuçlarının Değerlendirilmesi}

Laparoskopinin uygulanılabilirliği, invaziv cerrahiye kıyasla noninvaziv cerrahinin etkileyici sonuçlarına bağlıdır. İnsanlarda uygulanılan birçok cerrahi işlem, etkin ve düşük morbidite nedeniyle veteriner hekimlikte de yer almaktadır. Veteriner hekimlikte karaciğer, ekstrahepatik biliyer sistem, pankreas, böbrekler, dalak, bağırsak ve genitoüriner sistem dahil olmak üzere çeşitli organların noninvazif değerlendirilmesi için birçok teknik geliştirilmiştir. Çalışma materyallerini, abdominal organlarda problem şühpeli ve travma öyküsü olan farklı cins, yaş, cinsiyet ve ağırlıktaki yirmi kedi oluşturdu. Klinik incelemelerin ardından olgulara laparoskopik cerrahi uygulandı. Klinik muayenede vakaların tamamı vital olarak stabildi. Laparoskopik incelemede karaciğer, safra kesesi, mide, böbrek, bağırsaklar, mesane, uterus ve dalak net olarak izlendi. Olguların tamamına yakınında herhangi bir patoloji ile karşılaşılmazken; bir olguda dalak renginde değiş̧iklik gözlendi. Bazı olgularda kontrollü sistozentez uygulandı. Bu makale, kedilerde laparoskopi için gerekli ekipman ve tekniklerin gerekli olduğunu vurgulamaktadır. Laparoskopik muayenenin intraabdominal organların incelenmesinde veya patolojik kitlelere biyopsi uygulanmasında diğer yöntemlerine göre daha başarılı sonuçlar verdiği görülmektedir.

Anahtar Kelimeler: Abdomen, Kedi, Laparoskopi.

\section{INTRODUCTION}

In human medicine, minimally invasive surgery has been popular since the late 1980s. Developments in technology and advantages of minimally invasive surgery provide low postoperative pain and early return to daily activities in animals; thus, it is getting more and more attention in the veterinary field recently (Richter 2001). Laparoscopy in veterinary medicine makes it easier to direct intraabdominal examination of the organs and to take a biopsy from pathological masses. Laparoscopy mainly applies for diagnostic and therapeutic purposes (Webb and Trott 2008; Collard et al. 2010). For diagnostic purposes, the abdominal cavity, especially the peritoneum 
and organs, can be evaluated in general. Afterwards, direct application to organs or tissues and visual evaluations can be made. In this application, realistic information is provided especially about the spread of tumors. Diagnostic laparoscopy can be used especially for the size, condition, and definition of malignant tumors, as well as oncological evaluations of whether they are limited or metastatic. Also, bleeding caused by trauma, organ perforations can be detected. In this way, it provides a more accurate intervention chance. These are especially bladder ruptures, spleen diseases, internal bleeding due to pancreatitis (Webb and Trott 2008; Collard et al. 2010; Cosford et al. 2010; Freeman et al. 2010; Urbanová et al. 2011).

One of the most important applications in diagnostic laparoscopy is taking biopsy samples. Tissue samples taken with various biopsy forceps are of great clinical importance in terms of histopathological evaluation and diagnosis of diseases and determining their level. A similar application in routine laparotomy results in more blood and tissue perforation than in laparoscopy. Another application in diagnostic laparoscopy is the removal of pathological fluids. In this way, fluid is aspirated from organs such as the abdominal cavity, urinary bladder, and gall bladder, and histopathological evaluation is performed (Holak et al. 2010). The best advantages of laparoscopy compared to routine laparotomy surgery are fast recovery, low postoperative morbidity, low systemic infection rate, and less postoperative pain (Twedt and Monnet 2005; Collard et al. 2010). When faced with open laparotomy surgical techniques in small animals, it is seen that most of them can be performed by laparoscopic intervention. Common laparoscopic surgical techniques are cryptorchid surgery, overiohysterectomy and prophylactic gastropexy (Twedt and Monnet 2005; Collard et al. 2010).

Other laparoscopic surgical procedures performed include feeding tube placement with cystoscopy, jejunostomy or gastrotomy, gastric foreign body removal and adrenalectomy. Laparoscopic treatment indications vary depending on the experience of the surgeon and the types of laparoscopic instruments (Twedt and Monnet 2005; Webb and Trott 2008; Mathon et al. 2009; Mathon et al. 2011; Urbanová et al. 2011). Before the laparoscopic procedure can be prepared, the surgeon must have specific knowledge about pre-existing contraindications. Contraindications in laparoscopy; It can be divided into relative or precise and anatomical or physiological (Boute and McClaran 2015). Anatomical contraindications may include difficulty in accessing the cavity, obstruction of the peritoneal or thoracic cavity, organ enlargement, intestinal distension, congenital abnormalities, and the potential for cancer to spread (Bowers and Hunter 2006). Physiologically, contraindications include pregnancy, increased intracranial pressure, abnormal cardiac output and gas exchange in the lung, chronic liver disease and coagulopathy (Boute and McClaran 2015).

The present study, aimed to emphasize the superiority of diagnostic laparoscopy in cats with abdominal pathology.

\section{MATERIALS AND METHODS}

Twenty cats of different breeds, ages, genders, and weights with problems in the abdominal organs are suspected and a history of trauma were used as study material. After the clinical examinations, laparoscopic surgery was performed (Table 1). Selcuk University Faculty of Veterinary Medicine Experimental Animal Production and Research Center Ethics Committee (SÜVDAMEK) received ethics committee approval with the decision of 20.08 .2020 dated $2020 / 07$ meeting number 2020/76.

Blood parameters were measured before the operation. GEM Premier 3000 (USA) devices were used for blood gas and MS4e (Melet Schloesing, France) brand devices were used for hemogram measurements.

Table 1. Distribution of the cats used in the study by equals and study groups.

\begin{tabular}{|c|c|c|c|}
\hline Case & $\begin{array}{c}\text { Age } \\
\text { (Month) }\end{array}$ & Breed & Gender \\
\hline 1 & 36 & Mix & $0^{\prime \prime}$ \\
\hline 2 & 24 & Mix & q \\
\hline 3 & 12 & Mix & q \\
\hline 4 & 12 & Mix & q \\
\hline 5 & 12 & Mix & $0^{x}$ \\
\hline 6 & 24 & Mix & q \\
\hline 7 & 24 & Mix & q \\
\hline 8 & 12 & Mix & q \\
\hline 9 & 48 & Mix & $0^{x}$ \\
\hline 10 & 18 & Mix & $0^{x}$ \\
\hline 11 & 36 & Mix & $0^{x}$ \\
\hline 12 & 12 & Mix & 우 \\
\hline 13 & 24 & Mix & \% \\
\hline 14 & 18 & Mix & $0^{x}$ \\
\hline 15 & 12 & Mix & q \\
\hline 16 & 18 & Mix & q \\
\hline 17 & 24 & Mix & q \\
\hline 18 & 8 & Mix & q \\
\hline 19 & 6 & $\begin{array}{l}\text { British } \\
\text { Shorthair }\end{array}$ & $0^{x}$ \\
\hline 20 & 12 & Mix & 웅 \\
\hline
\end{tabular}

The patients were fasted 12 hours before the operation. Anesthesia was induced with domitor (medetomidine hydrochloride $0.08 \mathrm{mg} / \mathrm{mg}$ IM) and ketamine hydrochloride (Alfamine 10\%, 5-7.5 mg / ml Egevet, Izmir IM). The patients were intubated, and anesthesia was maintained with isoflurane (AErrane, Baxter 2\% -4\%). It was connected to the ECG monitor and the animal was fixed on the table in a ventro-dorsal position. The surgical intervention area asepsis and antisepsis was performed by first with povidone iode and then with alcohol $(70 \%)$ in accordance with the rules of asepsis and antisepsis. The area where the trocar and cannulas will be placed was determined. During laparoscopic examination, Sony LCD Monitor LMD-2140MD monitor, KARL STORZ telecam SL II, KARL STORZ xenon nova 175, KARL STORZ electronic endoflator devices were used. A 1-2 cm incision was made in the medial line. The abdominal cavity was reached by making a cross section through the linea alba. The pneumoperitoneum was created by a $70 \mathrm{~mm}$ long, $2 \mathrm{~mm}$ diameter veres needle. Veress needle or trocar secured with suture. Insufflation was done with $\mathrm{CO} 2$ gas. For this purpose, insufflation of gas up to $8-12 \mathrm{mmHg}$ was provided. Alternatively, the abdominal wall was raised by pulling two clips placed $3 \mathrm{~cm}$ on each side of the umbilicus, and the trocar was then inserted at a 90-degree angle. 
Providing adequate pneumoperitoneum and controlled placement of trocars are the reasons why this technique is safe (Figure 1). After the initial cannula was placed, the laparoscope was prepared for insertion into the abdomen (Figure 2).

In some cases, the tip of the laparoscope was kept in a container with warm physiological saline or sterile water to reduce the possibility of fogging of the lens as the laparoscope entered the abdominal cavity through the cannula. Routine preparations of the laparoscopy device were made. A 30-degree telescope and xeonon light source were inserted through the trocar. Before the camera was attached to the laparoscope in the abdominal cavity, the "white balance" was made by observing on the monitor. With the laparoscope connection, the focus was adjusted to give the camera a sharp and clear image. The camera was adjusted, then the laparoscope was passed through the cannula into the abdomen, and intraabdominal imaging was performed. After all stages were carried out, liver, gall bladder, stomach, spleen, small and large intestines, urinary bladder, and urinary system were examined with slow movements. Later, the animal was examined in lateral position to visualize the kidneys. The findings were recorded. For postoperatively synulox (Amoxicillin/clavulanic acid, $8.75 \mathrm{mg} / \mathrm{kg} \mathrm{SC}$ for 5 days once a day, Zoetis, Italy) and maxicam (Meloxicam, 0.1-0.2 $\mathrm{mg}$ / kg SC, Sanovel, Turkey) was given.

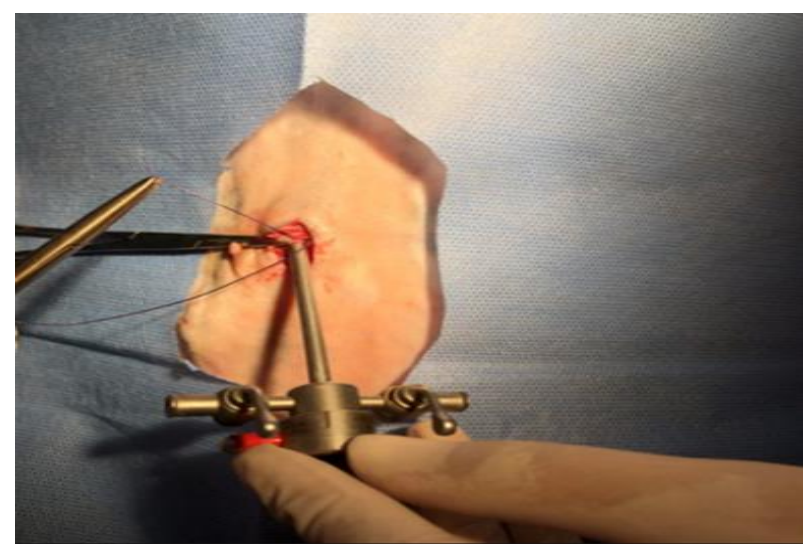

Figure 1. Placement of the trocar in the abdomen.

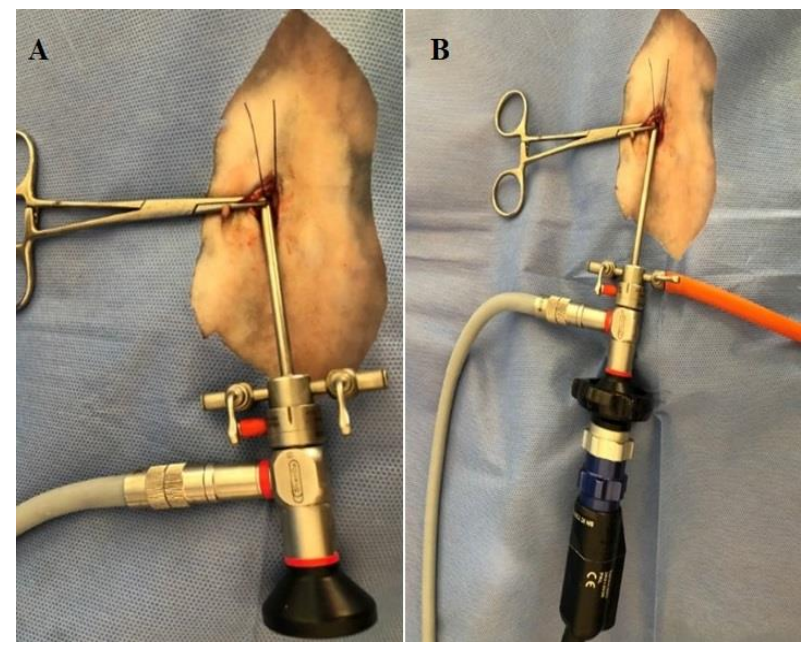

Figure 2. A: Fixing the trocar with tobacco pouch stitching and placement of the xeonon light source in the trocar. B: Insufflator cable and camera placement in trocar.

\section{RESULTS}

Before laparoscopic surgery in all cases, complete blood count (CBC), blood gases, acid-base status, electrolyte and metabolite values were examined, and the cases were evaluated.

\section{Laparoscopic Findings \\ Liver and Gallbladder Findings}

In the laparoscopic examination of the liver and gall bladder, a routine laparoscopy technique was approached in the ventro-dorsal position, and no serious problem was encountered (Figure 3). The liver was examined in terms of color, location, and size, yet no serious pathology was found in the cases. Liver and gall bladder laparoscopy technique and manipulation were found to be easy and advantageous.

\section{Stomach Findings}

In gastric laparoscopy examination, a routine laparoscopy technique was approached in the ventro-dorsal position, and no serious problem was observed. The position was examined in the direction of dilatation and no pathology was observed in the cases (Figure 4).

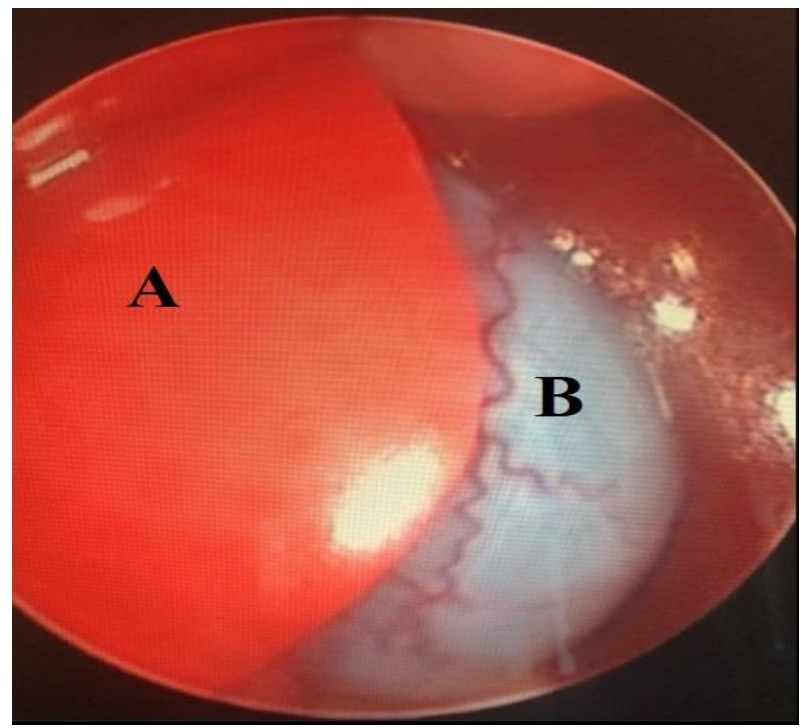

Figure 3. Case no. 2, 2 years old mix breed male cat, A: Liver, B: gallbladder.

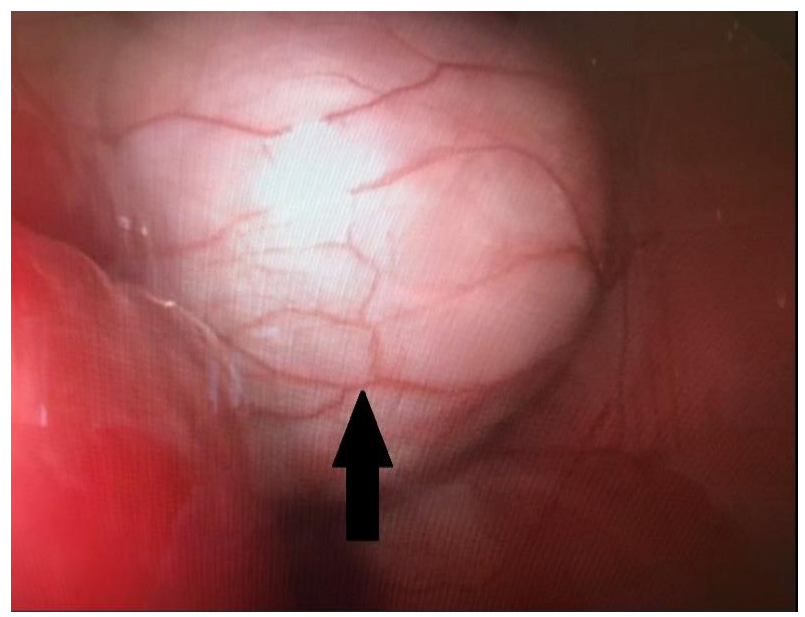

Figure 4. Case no. 4, 1 year old mix breed female cat, black arrow: stomach. 


\section{Spleen Findings}

In the laparoscopic examination of the spleen, a routine laparoscopy technique was approached in the ventrodorsal position, and no serious problem was seen. Ageindependent color change was detected in the spleen of only case number 7. Age-related color changes were observed in other cases.

\section{Kidney Findings}

In the renal laparoscopic examination ventro-dorsal approach was provided with the routine laparoscopy technique, and the image of the right kidney was not obtained in this position. The right kidney could be reached when the cases were placed in the left lateral position (Figure 5). No pathology was also found.

\section{İntestinal Findings}

In the small and large bowel laparoscopy examination, an approach was provided with a routine laparoscopic technique in the ventro-dorsal position. Content and peristaltic movements were observed in the cases. No pathology was found.

\section{Bladder Findings}

In the laparoscopic examination of the urinary bladder, an approach was provided with the routine laparoscopy technique in the ventro-dorsal position. The urinary bladder was clearly observed in all cases. In some cases, no pathology was found except color change. Laparoscopy was found to be advantageous in terms of cystocentesis.

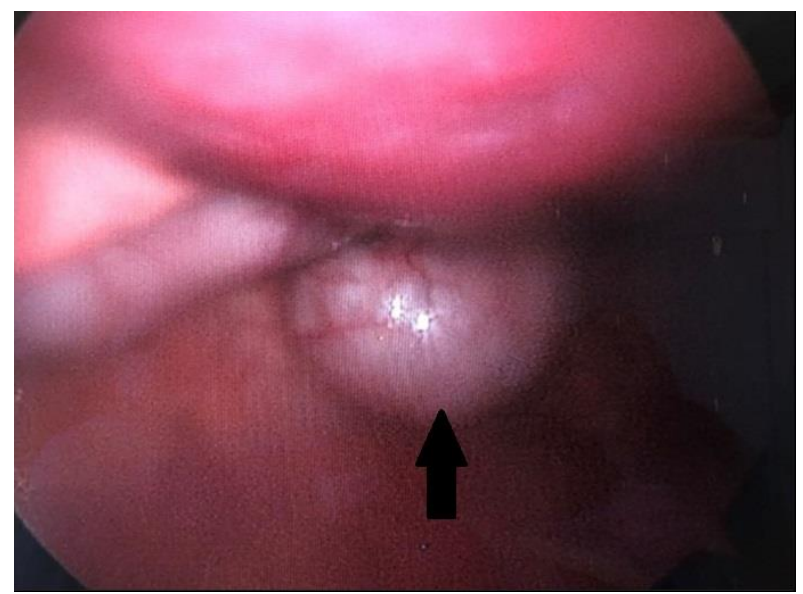

Figure 5. Case no. 4, 1 year old mix breed female cat, black arrow: left kidney.

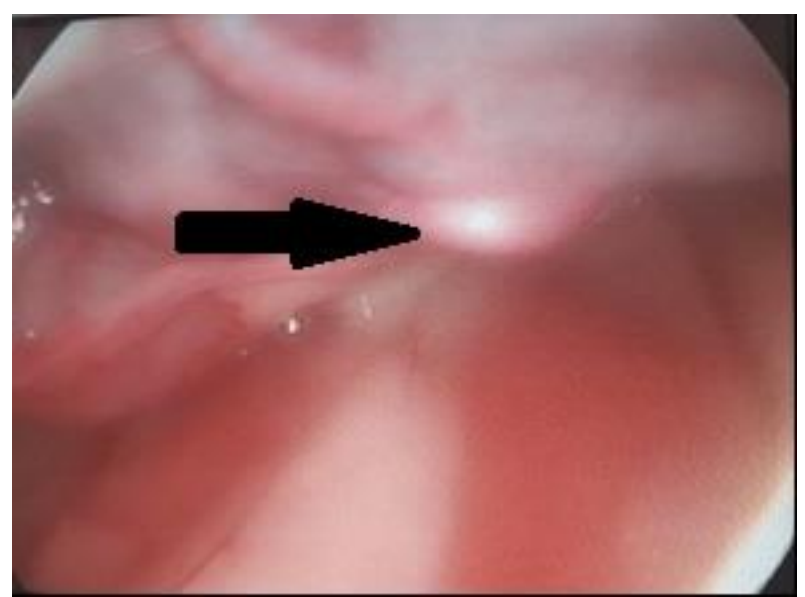

Figure 6. Case no. 6, 2 years old mix breed female cat, black arrow: ovarium.

\section{Ovary findings}

In the laparoscopic examination of the ovary, only the case no. 6 ovaries (Figure 6) were observed in the ventrodorsal position. In other female cases, ovaries could not be observed due to unknown reasons.

\section{DISCUSSION AND CONCLUSION}

Laparoscopic surgery techniques have been widely applied in veterinary medicine recently. Surgical operations performed by laparoscopic methods are characterized by minimal invasive, rare complications and low mortality. The application of modern laparoscopic techniques makes it possible to significantly shorten the hospitalization period of the patients, guaranteeing faster recovery and bringing higher satisfaction to animal owners and physicians (Matyjasik et al. 2011).

Although $\mathrm{CO} 2$ can react with the fluid in the abdominal cavity and irritate the peritoneum by producing carbonic acid, it is preferred in studies because it is less irritant than other gases (Gomez and Viloria 2019). Although it has been reported that complications related to CO2 may develop, no complications related to this were observed in any of the cases in our study. Intestinal and stomach injuries can cause peritonitis as a result of the contents entering the abdomen (Stuart Wolf and Stoller 1994). Although ascites was not observed during the examination of the abdomen in the cases used in the study, ascites was also encountered in diseases related to kidney or liver. In cases with ascites, it is not possible to properly visualize the abdominal cavity organs and laparoscopic procedure is difficult to perform due to fluid accumulation. In cases with ascites, large-volume paracentesis can be performed as the first step in laparoscopy (Sussman et al. 1999). Examination and biopsy of the intestinal system can only be done by laparoscopy to a limited extent (Richter 2001). In our study, the intestines were full of content and peristaltic movements were observed in the cases.

In a study conducted by Webb and Trott with 18 dogs and 13 cats with clinical symptoms, abnormalities in the pancreas were detected in 20 of the animal's laparoscopic pancreatic biopsies (Webb and Trott 2008; Cosford et al. 2010; Freeman et al. 2010). It was found that the histological findings of the samples taken in surgical biopsy applications and the histological findings between the biopsies taken by laparoscopy were more than $50 \%$ compatible (Moran et al. 2011; Urbanová et al. 2011).

Conclusion of the study were shown that laparoscopic examination enables visual evaluation of changes in organs or tissues. Color and pathological changes in organs are seen visually. Bleeding as a result of trauma and organ perforations can be detected with laparoscopic examination. In this way, such as bladder ruptured, spleen diseases, bleeding due to pancreatitis it provides a more accurate intervention chance. In some cases, in the advanced stages of the disease, ultrasound and radiography give results for some structural changes in the organs. But one of the most important applications in diagnostic laparoscopy is the early biopsy sample. Thus, early diagnosis is provided. While the presence of pathological fluid is observed with the ultrasonographic examination, another application in diagnostic laparoscopy is the removal of pathological fluids. Therapeutic indications for laparoscopy are rapid recovery, low postoperative morbidity, low systemic infection rate and less postoperative pain. 
Further studies with a larger group of cats should be considered to compare the efficacy of laparoscopy and other diagnostic techniques and long-term evaluation for abdominal diseases.

\section{CONFLICT OF INTEREST}

The authors declare that they have no conflict of interest.

\section{ACKNOWLEDGEMENT}

This research was supported by Selçuk University Scientific Research Projects Directorate with the project 20212037.

\section{AUTHOR CONTRIBUTIONS}

\section{Idea/Concept: MA}

Supervision/Consultancy: MA

Data Collection and/or Processing: MB, EOU

Analysis and/or Interpretation: MA, MB, EOU

Literature Review: MA, MB, EOU

Critical Review: MA, MB, EOU

\section{REFERENCES}

Boute N, McClaran J (2015). Laparoscopic contraindications, complications and conversions In: Small Animal Laparoscopy and Thoracoscopy, Mayhew PD, Fransson BA (Eds), 180-192. WileyBlackwell, New Jersey.

Bowers SP, Hunter JG (2006). Contraindications to laparoscopy. Whelan RL, Fleshman JW, Fowler DL (Eds). The Sages Manual (pp. 25-32). Springer, New York.

Collard F, Nadeau ME, Carmel ÉN (2010). Laparoscopic splenectomy for treatment of splenic hemangiosarcoma in a dog. Vet Surg, 39 (7), 870 872.
Cosford K, Shmon C, Myers S et al. (2010). Prospective evaluation of laparoscopic pancreatic biopsies in 11 healthy cats. J Vet Intern Med, 24 (1) 104-13.

Freeman LJ, Rahmani EY, Al-Haddad Met al. (2010). Comparison of pain and postoperative stress in dogs undergoing natural orifice transluminal endoscopic surgery, laparoscopic, and open oophorectomy. Gastrointest Endosc, 72 (2), 373-80.

Gómez-Arrue J, Viloria AJ (2019). Laparokopi ve Cerrahi. Rodríguez J (Ed). Hayvan Cerrahisi (pp. 201-206). Güneş, Ankara.

Holak P, Adamiak Z, Jałyński M, Chyczewski M (2010). Laparoscopyguided prostate biopsy in dogs-a study of 13 cases. Pol J Vet Sci, 13 (4), 765-766.

Mathon DH, Dossin O, Palierne S et al. (2009). A laparoscopic-sutured gastropexy technique in dogs: mechanical and functional evaluation. Vet Surg, 38 (8), 967-74.

Mathon DH, Palierne S, Meynaud-Collard P et al. (2011). Laparoscopicassisted colopexy and sterilization in male dogs: short-term results and physiologic consequences. Vet Surg, 40 (4), 500-508.

Matyjasik H, Adamiak A, Pesta W, Zhalniarovich Y (2011). Laparoscopic Procedures in Dogs and Cats. Pol J Vet Sci, 14 (2), 305-316.

Moran E, Hanes M, Huebner M, Gostout CJ, Bingener J (2011). Pulmonary and peritoneal inflammatory findings in transgastric NOTES compared with laparoscopy: pooled analysis from randomized porcine survival studies. Gastrointest Endosc, 74 (5), 1103-7.

Richter KP (2001). Laparoscopy in dogs and cats. Vet Clin North Am Small Anim Pract, 31 (4), 707-727.

Stuart Wolf J, Stoller ML (1994). The physiology of laparoscopy: basic principles, complications and other considerations. J Urol, 152 (2), 294 302.

Sussman L, Lewis M, Secker A et al. (1999). Randomized clinical trial of early laparoscopy in the management of acute non-specific abdominal pain. BrJ Surg, 86 (11), 1383-1386.

Twedt DC, Monnet E (2005). Laparoscopy: technique and clinical experience. McCarthy TC (Ed). Veterinary endoscopy for the small animal practitioner (pp. 357-385). Elsevier, Missour.

Urbanová L, Crha M, Raušer $\mathbf{P}$, Nečas A (2011). Clinical results and complications of preventive laparoscopic assisted gastropexy in 17 dogs: preliminary study. Acta Vet Brno, 80 (1), 93-99.

Webb C, Trott C (2008). Laparoscopic diagnosis of pancreatic disease in dogs and cats. J Vet Intern Med, 22 (6), 1263-1266. 